\title{
Male sterility induced by the chemical hybridizing agent clofencet on wheat, Triticum aestivum and T. turgidum var. durum
}

\author{
Patricio C. Parodi ${ }^{1}$, and María de los Angeles Gaju ${ }^{2}$ \\ 'Escuela de Agronomía. Facultad de Recursos Naturales, Universidad Católica de Temuco, Casilla 15-D, Temuco \\ ${ }^{2}$ Departamento de Ciencias Vegetales, Facultad de Agronomía e Ingeniería Forestal, Pontificia Universidad \\ Católica de Chile.
}

\begin{abstract}
P.C. Parodi, and M.A. Gaju. 2009. Male sterility induced by the chemical hybridizing agent clofencet on wheat, Triticum aestivum and T. turgidum var. durum. Cien.Inv.Agr. 36(2):267-276. The objective of this experiment was to evaluate the male sterilizing activity induced by the chemical hybridizing agent (CHA) clofencet, on four wheat varieties: two Triticum aestivum cultivars, 'Pia' and 'Claudia', and two Triticum turgidum var. durum cultivars, 'Capri' and 'Ambra'. The CHA was sprayed at two stages of the Feekes scale, 7.5 and 8.5, using four rates of active ingredients $\left(0,3.5,5.0\right.$ and $\left.6.5 \mathrm{~kg} \cdot \mathrm{ha}^{-1}\right)$ in a split block design with five replicates. The efficiency of the treatments was determined by measuring developed seeds and calculating male sterility (MS). Results showed that MS increased with increasing dosage and was more pronounced at the latest stage of development. The MS average for the highest dosage was $47.3 \%$ in the first stage of application and reached $84 \%$ at the second stage of application. Cultivars responded differently to the CHA, but no differences clearly attributable to species could be detected. T. aestivum cultivar 'Pia' reached $96 \% \mathrm{MS}$, a value that justifies the use of clofencet as a CHA for hybrid wheat production. The insufficient levels of MS detected in the other cultivars were due to causes not determined in this study.
\end{abstract}

Key words: Triticum aestivum, Triticum turgidum, hybrid seed, male sterelizing, chemical hybridizing.

\section{Introduction}

Wheat (Triticum spp.) is an autogamous plant with perfect flowers producing limited amounts of pollen, and it is characterized by a relatively short period of gynoecium receptivity. Genetic improvement of wheat has been a matter of considerable concern through the years, mainly to increase yields, minimize losses due to unfavorable environmental conditions, and develop

Received 28 June 2007. Accepted 28 September 2007.

Corresponding author: pparodi@uct.cl resistance to pests and diseases (Pingali and Rajaram, 2000).

With 8,000 years of history, wheat is the main cereal in the diet of mankind. Its global production is currently 640 million tons a year, and production has increased in accordance with the increase in population. In the last fifty years, wheat production had increased nearly $1 \%$ per year. This is due to technological advances in genetically more productive cultivars and the adoption of better cultivation practices. By 2025, it is expected that a yearly increase in yield of about $2.5 \%$ will be required to meet the needs of a growing population demanding more food (Curtis, et al., 2002). One way to increase wheat 
productivity is to use heterosis for improvement of yield and other features in hybrid cultivars.

Wheat genetics is relatively complex, presenting an extensive (around 16 billion base pairs) and complex (hexaploid and tetraploid) genome with a high percentage of repetitive sequences (80\%), which hinders its study and handling (Skovmand et al., 2003).

The investigation and development of wheat hybrids began in the 1950s (Pickett, 1993). The advent of cytoplasmic male sterility (CMS) allowed the production of hybrid seeds on a commercial scale, and it has replaced the manual emasculation previously used for wheat hybrid production. The limited pollen production by male wheat lines (e.g., compared with corn), determines that the degree of relatedness between male and female lines should be relatively high, which makes the yield of hybrid seeds low (McRae, 1985; Duvick, 1999).

Commercial wheat hybrids have been produced using chemical hybridizing agents (CHA), which are growth regulators interfering selectively with the development of pollen or natural systems of male fertility(McRae, 1995; Duvick, 1999). In 1997, the Environmental Protection Agency (EPA) of the USA registered clofencet (Genesis) as an androsterility agent for wheat. This and other CHAs (e.g., Sogital SC2053) are used for wheat hybrid production. With the development of CHA technology, a notable decrease in the investigation of CMS as a system of hybrid production has been observed. Rajaram (1999) says that a system of cytoplasmic sterility based on sterility derived from $T$. timopheevii has allowed partial success in the creation of wheat hybrids.

Wheat hybrids have shown significantly higher yields and better adaptation to adverse environments than the best homozygous genotypes (Parodi et al., 1970; Edwards, 1986; Bingham and Lupton, 1987; Wassell and Weaver, 1995; Braun et al. 1998; Uauy et al., 2003). However, the effectiveness of wheat hybrids has been questioned because heterosis may be fixed as they accumulate the best alleles in conventional genotypes, forming homozygous cultivars that are superior to hybrids (Uauy et al., 2003).
Other estimates of hybrid vigor can be found in Bingham and Lupton (1987) and Bruns and Peterson (1998).

The first report of the effects of CHA on spring wheat was a study on the effects of maleic hydrazide on suppressing pollen development (Hoagland et al., 1953). Subsequently, considerable advances in the development of CHAs have occurred (Mock, 1995). Compared with CMS, an effective CHA allows the production of a high number of parental combinations and allows the evaluation of a great number of lines for combining capacity and genetic value. This substantially reduces the time required for hybrid development (Bruns and Peterson, 1998).

The first generation of CHAs (e.g., ethylene, gibberellins) was developed for other purposes. In general, they were phytotoxic at the doses required to produce effective sterility. They frequently presented low female receptivity or fertility or did not produce adequate male sterility. The second generation of CHAs (e.g., RH0007 (Hy-brex) used in the USA and Europe) works in a narrow range of conditions, including a reduced window of application and a reduced number of genotypes susceptible, otherwise phytotoxicity can occur. Rathgeb et al. (1982a,b), worked with DPX 3778 and Ethrel in wheat and triticale (X Triticosecale) obtaining $87.5 \%$ and $76.3 \%$ male sterility (MS) induction in wheat, respectively. A MS induction of primary ears was not observed in triticale. In both species, only Ethrel was phytotoxic.

The current generation of CHAs are pollen suppressors (e.g., WL 84811, Shell; clofencet (Genesis), Monsanto), which are safe, have low phytotoxic effects, allowing better quality seeds, and can be used in a great number of genotypes. WL 84811 was discontinued, but Genesis has been registered for hybrid seed production in the USA and France.

The attributes of a good CHA include (Liable, 1974; Virmani and Edwards; 1983; Pickett, 1993): 1. Induces only male sterility, without affecting female fertility, 2 . Produces easily recognizable androsterility, 3 . Lacks phytotoxic effects on the treated progenitor, 4 . Is effective on all the genotypes of a species, 5. Is effective in 
a wide range of environments, 6 . Has systemic activity and persistence to sterilize early and late clusters of all the plants of the treated population, 8 . Allows for flexibility in the application stage to overcome adverse climatic conditions and allow the treatment of large surfaces, 9. has great dose flexibility to allow a secure margin of application, 10 . Achieves sterility with only one treatment, 11 . Does not affect the quality of $F_{1}$ seed or the vigor of either plantlets or plants $F_{1}, 12$. Can be applied into the seed, 13. Is effective over several genus. Is economical to synthesize and practical to apply, and 15. Is safe and without negative ecotoxicological effects on the environment.

Clofencet has almost all the attributes of an ideal CHA, except for the impossibility of applying it to the seed. Although clofencet can effectively sterilize all the genotypes of T. aestivum, different doses are required for different genotypes (Cisar and Cooper, 2003). Its effect on T. turgidum is unknown.

The advantages of the use of CHA include the use of simple protocols of plant improvement, as in this system neither the conversion and maintenance of an androsterile line (line A) nor the incorporation of factors of fertility restoration in male progenitors is required (Cross and Schulz, 1997, Cisar and Cooper, 2003). Even the genotypes with low extrusion of stamens may be used as male progenitors. The evaluation of a great number of genotypes for general and specific combining capacity as well as for characteristics of seed production becomes easier. Heterogeneous populations may be developed or improved. The disadvantages of CHAs include: (1) Less seed production in females treated with CHAs versus females with CMS, due to effects of overdose. (2) Generation of undesired morphological changes. (3) Difficulties in field applications due to rains or winds. (4) Evaluation required for the interaction of genotypic and environmental factors. (5) Androfertility, or self-pollination of the female progenitor, which may be expressed as substandard seed quality, and (6) Costs associated with the investigation, identification, development, and recording of the compound.

However, it is noteworthy that some of these disadvantages also exist with the CMS system. For example, the genotype $\mathrm{x}$ environment in- teractions are also a problem when developing males with adequate fertility restoration in a range of environments. Likewise, male fertility may also become a problem in a CMS female without a stable cytoplasmic sterility, or with a line B that cannot be transformed into complete pollen sterility (Wilson, 1984).

Other hybridization systems have been proposed, including recessive male sterility genes combined with chemical restoration of fertility (Wilson, 1984); male nuclear sterility (MNS), as the XYZ system of Driscoll (1985), or photo thermal-sensible systems that require different photoperiods and thermal regimes (He et al., 1998; Murray, 1998). With the continuous development of biotechnology, the development of hybridization systems through genetic engineering may be feasible. However, the use of CHAs to develop phytoimprovement populations and to identify specific hybrids to be converted to heredity systems of nuclear sterility to produce hybrids, seems efficient and may be necessary (Cisar and Cooper, 2003).

Clofencet acts systemically, moving from leaves to flowers. It causes pollen sterility (Fichet and Adams, 1996), which makes treated plants suitable for use as females in crosses. For an effective production of hybrid seeds, a MS $>95 \%$ should be reached. This guarantees a high level of seed purity, where the resulting seed may be classified as pure hybrid (Wassel and Weaver, 1995). The results reported by Wassell and Weaver (1995), Nesvadba and Vyhnánek (2001), and Nesvadba et al. (2001) reached a MS $>50 \%$ with low doses of clofencet, and between 95 and $100 \%$ with doses between 3.6 and $4.9 \mathrm{~kg} \cdot \mathrm{ha}^{-1}$.

The first commercial production of wheat hybrids in the USA began with the Quantum series in 1996, using clofencet. At least five wheat hybrids have been recorded in France since 1995, and in Germany the first hybrid was recorded in 1999 (Nesvadba et al., 1998).

The objective of this investigation was to study the effectiveness of clofencet in cultivars of the wheat species T. aestivum and T. turgidum var. durum. The effectiveness of clofencet in T. turgidum var. durum is unknown. 


\section{Materials and methods}

\section{Test location}

The experiment was performed in the Experimental Station, Pontificia Universidad Católica de Chile, in Curacaví using T. aestivum cvs. 'Claudia' and 'Pía', and T. turgidum var. durum cvs. 'Capri' and 'Ambra'.

\section{Treatments}

Clofencet (Genesis, Monsanto, USA), at the rates of $3.5,5.0$, and $6.5 \mathrm{~kg} \cdot \mathrm{ha}^{-1}$, was sprayed when wheat on average was at the 7.5 stage (44 $\mathrm{mm}$ spikes) and 8.5 stage (176 mm spikes) of the Feekes scale. A manual back pump, with a bar with cone fan sprays (Albuz type axi 11003) separated at $50 \mathrm{~cm}$, was used. A total volume of $500 \mathrm{~L} \cdot \mathrm{ha}^{-1}$ was applied along with $250 \mathrm{~mL} \cdot \mathrm{ha}^{-1}$ of surfactant (Dash HC, BASF, Santiago, Chile).

To avoid external pollen contamination, 10 spikes from each plot were isolated with paper bags before anthesis. A pollen sample from plots treated with the highest dose of clofencet and untreated plots was collected and stained with diamond fuchsine (Calcozine fuchsine). Morphological differences in the pollen from treated and control plants under light microscope.

Only the bagged spikes were harvested from each plot. Spikes were threshed manually and seeds were counted. The male sterility (MS) induced in each cultivar was calculated with the following equation:

$\operatorname{MST}_{i}=1-\left(\mathrm{N}_{\mathrm{i}} / \mathrm{N}_{\mathrm{t}}\right) \cdot 100$

where, $\mathrm{MST}_{\mathrm{i}}=$ male sterility of the treatment $T_{i}, T_{i}=$ number of treatments (for $i=0,1,2, \ldots ., 6$ ), $\mathrm{N}_{\mathrm{i}}=$ average number of seeds for each treatment $\mathrm{T}_{\mathrm{i}}, \mathrm{N}_{\mathrm{t}}=$ number of average control seeds.

\section{Sowing and fertilization}

The experiment was conducted on 160 plots, each $2 \mathrm{~m}^{2}(1 \times 2 \mathrm{~m})$, manually sown with ap- proximately $250 \mathrm{seed} \cdot \mathrm{sm}^{-2}$. The plots were fertilized with $48 \mathrm{~kg} \cdot \mathrm{ha}^{-1}$ of nitrogen $(\mathrm{N})$ applied as urea and $42 \mathrm{~kg} \cdot \mathrm{ha}^{-1}$ of $\mathrm{P}_{2} \mathrm{O}_{5}$ applied as triple superphosphate incorporated before sowing and $48 \mathrm{~kg} \cdot \mathrm{ha}^{-1}$ of $\mathrm{N}$ as urea applied at the beginning of tilling. Weeds were controlled manually.

\section{Design and statistical analysis}

Treatments were randomly distributed according to a split block design (dates and rates) with five replicates.

To evaluate the effect of the CHA treatments with respect to the control, the results were analyzed, first according to a complete randomized block model with seven treatments (control plus three doses in two application dates) and five replicates. The second analysis was done using split blocks to study the effect among the CHA doses used, application dates, and the interaction between these two factors. Means were separated on the basis of Dunnett's test ( $p \leq$ 0.05). The SAS program (SAS Institute, Cary, NC, USA) was used.

\section{Results}

Analysis of variance and multiple range tests

According to the analysis of variance, the effect of treatments were significant, and mean differences among treatments and controls were also statistically significant for each $T$. aestivum and T. turgidum cultivar. In wheat 'Ambra' and 'Pía', mean differences in seed numbers among all treatments were significant in relation to the control, while in 'Claudia' and 'Capri' significant differences only were obtained for the highest clofencet dose, when applied in the first stage of wheat growth development, but all treatments were significantly different from the control treatment when clofencet was applied in the second stage of wheat growth development (Table 1).

There was a significant effect among application dates (Table 2) and among clofencet doses applied to T. aestivum and T. tugidum cultivars (Table 3 ). The cultivar 'Ambra' was analyzed separately due 
Table 1. Differences between treatments' and controls' average seed numbers, with their respective standard deviations.

\begin{tabular}{|c|c|c|c|c|c|c|c|c|}
\hline \multirow{4}{*}{$\begin{array}{c}\text { Clofencet } \\
\text { treatments } \\
\mathrm{kg} \cdot \mathrm{ha}^{-1}\end{array}$} & \multicolumn{8}{|c|}{ Wheat species and cultivars: seeds, no. } \\
\hline & \multicolumn{4}{|c|}{ Triticum turgidum var. durum } & \multicolumn{4}{|c|}{ Triticum aestivum } \\
\hline & \multicolumn{2}{|c|}{ 'Ambra' } & \multicolumn{2}{|c|}{ 'Capri' } & \multicolumn{2}{|c|}{ 'Claudia' } & \multicolumn{2}{|c|}{ 'Pía' } \\
\hline & Mean & $\mathrm{SD}^{1}$ & Mean & $\mathrm{SD}^{1}$ & Mean & $\mathrm{SD}^{1}$ & Mean & $\mathrm{SD}^{1}$ \\
\hline & \multicolumn{8}{|c|}{ First application date, Feekes stage 7.5} \\
\hline 0.0 & 38.57 & 2.55 & 33.31 & 1.73 & 40.48 & 2.15 & 45.33 & 1.89 \\
\hline 3.5 & $30.70^{*}$ & 3.52 & 30.36 & 4.38 & 34.90 & 4.92 & $28.48^{*}$ & 8.18 \\
\hline 5.0 & $22.52 *$ & 3.67 & 27.45 & 1.81 & 33.22 & 5.82 & $21.73 *$ & 5.10 \\
\hline \multirow[t]{2}{*}{6.5} & $18.39 *$ & 2.39 & $23.34 *$ & 4.51 & $26.58^{*}$ & 5.38 & $12.41 *$ & 8.39 \\
\hline & \multicolumn{8}{|c|}{ Second application date, Feekes stage 8.5} \\
\hline 0.0 & 38.57 & 2.55 & 33.31 & 1.73 & 40.48 & 2.15 & 45.33 & 1.89 \\
\hline 3.5 & $16.59^{*}$ & 4.84 & $19.26^{*}$ & 5.56 & $23.77^{*}$ & 3.66 & $11.10^{*}$ & 6.85 \\
\hline 5.0 & $17.51^{*}$ & 2.70 & $14.90^{*}$ & 7.69 & $16.75^{*}$ & 4.64 & $8.55^{*}$ & 5.34 \\
\hline 6.5 & $4.09 *$ & 3.53 & $8.93 *$ & 1.26 & $8.81^{*}$ & 1.85 & $1.67 *$ & 2.11 \\
\hline
\end{tabular}

${ }^{1}$ Standard deviations. *Mean differences significant from control treatments according to Dunnett's test $(\mathrm{p}=0.05)$.

Table 2. Mean values of seed formation obtained on wheat treated with clofencet at each stage of development.

\begin{tabular}{|c|c|c|c|}
\hline \multirow{3}{*}{$\begin{array}{l}\text { Wheat growth } \\
\text { development, } \\
\text { Feekes'scale }\end{array}$} & \multicolumn{3}{|c|}{ Wheat species and cultivars: seed, no. } \\
\hline & \multirow{2}{*}{$\begin{array}{c}\text { T. turgidum var. durum } \\
\text { 'Capri' }\end{array}$} & \multicolumn{2}{|c|}{ T. aestivum } \\
\hline & & 'Claudia' & 'Pía' \\
\hline 7.5 & $27.05^{* *}$ & $31.56^{* *}$ & $20.87 * *$ \\
\hline 8.5 & 14.36 & 16.44 & 7.10 \\
\hline
\end{tabular}

Table 3. Mean wheat seed number per cultivar obtained for each rate of clofencet

\begin{tabular}{cccc}
\hline & \multicolumn{3}{c}{ Wheat species and cultivar: seeds, no. } \\
\cline { 2 - 4 } Clofencet & T. turgidum var. durum & \multicolumn{2}{c}{ T. aestivum } \\
'Capri' & $24.82 \mathrm{a}^{-1}$ & 'Claudia' & 'Pía' \\
\hline 3.5 & $21.17 \mathrm{~b}$ & $29.33 \mathrm{a}$ & $19.79 \mathrm{a}$ \\
5.0 & $16.14 \mathrm{c}^{* *}$ & $24.99 \mathrm{~b}$ & $15.14 \mathrm{a}$ \\
6.5 & $17.69 \mathrm{c}^{* *}$ & $7.04 \mathrm{~b}^{* *}$ \\
\hline
\end{tabular}

${ }^{1}$ Means followed by the same lower or upper case letters are not statistically significant according to StudentNewman-Keuls $(\mathrm{SNK})$ analysis $(\mathrm{p}=0.05)$ and $* *$ indicates significant differences based on Tukey and Kramer analysis $(\mathrm{p}=0.05)$.

to the existence of significant interaction among these factors. Nevertheless, on the second application date, the effect of the two first clofencet doses was not statistically different, showing a significant drop in seed number only with the highest clofencet dose (data not shown).

\section{Induction of male sterility}

Seed formation in response to developmental growth stages of wheat and clofencet doses are presented in Table 1. The MS induction 
Table 4. Male sterility achieved by wheat (Triticum turgidum var. durum) cultivars 'Ambra' and 'Capri' and by wheat (T. aestivum) cultivars 'Claudia' and 'Pia' subjected to clofencet treatments at two stages of wheat development.

\begin{tabular}{|c|c|c|c|c|c|c|}
\hline \multirow{3}{*}{$\begin{array}{c}\text { Clofencet } \\
\text { treatments } \\
\mathrm{kg} \cdot \mathrm{ha}^{-1}\end{array}$} & \multicolumn{6}{|c|}{ Wheat species and cultivars: $\%$ male sterility } \\
\hline & \multicolumn{3}{|c|}{ Triticum turgidum var. durum } & \multicolumn{3}{|c|}{ Triticum aestivum } \\
\hline & 'Ambra' & 'Capri' & Mean & 'Claudia' & 'Pía' & Mean \\
\hline & \multicolumn{6}{|c|}{ First application date, Feekes stage 7.5} \\
\hline 0.0 & $0.00 \mathrm{i}^{1}$ & $0.00 \mathrm{i}$ & $0.00 \mathrm{H}^{2}$ & $0.00 \mathrm{i}$ & $0.00 \mathrm{i}$ & $0.00 \mathrm{H}$ \\
\hline 3.5 & $20.40 \mathrm{fg}$ & $8.83 \mathrm{~h}$ & $14.62 \mathrm{G}$ & $13.78 \mathrm{~g}$ & $37.17 \mathrm{e}$ & $25.48 \mathrm{~F}$ \\
\hline 5.0 & $41.61 \mathrm{~d}$ & $17.59 \mathrm{~g}$ & $29.60 \mathrm{~F}$ & $17.92 \mathrm{~g}$ & $52.07 \mathrm{~cd}$ & $35.00 \mathrm{E}$ \\
\hline \multirow[t]{2}{*}{6.5} & $52.32 \mathrm{~cd}$ & $29.92 \mathrm{f}$ & $41.12 \mathrm{D}$ & $34.33 \mathrm{e}$ & $72.62 b$ & $53.48 \mathrm{C}$ \\
\hline & \multicolumn{6}{|c|}{ Second application date, Feekes stage 8.5} \\
\hline 0.0 & $0.00 \mathrm{i}$ & $0.00 \mathrm{i}$ & $0.00 \mathrm{H}$ & $0.00 \mathrm{i}$ & $0.00 \mathrm{i}$ & $0.00 \mathrm{H}$ \\
\hline 3.5 & $56.98 \mathrm{c}$ & $42.16 \mathrm{~d}$ & $49.57 \mathrm{CD}$ & $41.27 \mathrm{~d}$ & $75.51 \mathrm{~b}$ & $58.39 \mathrm{C}$ \\
\hline 5.0 & $54.60 \mathrm{c}$ & $55.27 \mathrm{c}$ & $54.94 \mathrm{C}$ & $58.62 \mathrm{c}$ & $81.14 \mathrm{ab}$ & $69.88 \mathrm{~B}$ \\
\hline 6.5 & $89.41 \mathrm{a}$ & $73.18 b$ & $81.30 \mathrm{~A}$ & $78.24 b$ & $96.32 \mathrm{a}$ & $87.28 \mathrm{~A}$ \\
\hline
\end{tabular}

${ }^{1}$ Means followed by the same lower or upper case letters are not statistically significant according to Dunnett's test $(\mathrm{p}=0.05)$.

increased within each application date in response to growing doses of clofencet. Nevertheless, there were differences among application dates, so that the application made in stage 8.5 of the Feekes scale induced MS values that were significantly higher than those induced by the application made with to less developed plants (7.5 on the Feekes scale) (Table 4).

The responses of the two wheat species analyzed were also different. In T. turgidum var. durum, the average of MS induced at each application date and with each clofencet dose was lower than the average induced in T. aestivum (Table 4). Within T. turgidum var. durum, there were also differences in the cultivars' response with higher MS induction in the cultivar 'Ambra' than in 'Capri'. Nevertheless, in both cultivars, the highest MS percentage was obtained when the highest clofencet dose $\left(6.5 \mathrm{~kg} \cdot \mathrm{ha}^{-1}\right)$ was used in wheat at the 8.5 growth stage of the Feekes scale. MS values of $89.41 \%$ and $73.18 \%$ were obtained for cvs. 'Ambra' and 'Capri', respectively (Table 4).

In T. aestivum, the MS induction was adjusted to a general pattern similar to the pattern described for T. turgidum var. durum, but with some relevant differences (Table 4). There were consistent differences among cultivars at both stages of development and with all the clofencet doses. For the earlier application date, the cultivar 'Pia' produced $111.5 \%$ more male sterility at the highest clofencet dose and $190.6 \%$ more male sterility at the medium dose, than the cultivar 'Claudia'. These differences were lower for the application made in the second growth stage. In this case, the cultivar 'Pia' produced $23.11 \%$ and $82.72 \%$ more MS with the highest and lowest clofencet dose, respectively. The highest MS was obtained in 'Pía' with $6.5 \mathrm{~kg} \cdot \mathrm{ha}^{-1}$ of clofencet applied at stage 8.5 of the Feekes scale (Table 4).

\section{Microscopic analysis of pollen}

Microscopic observation of the pollen grains revealed morphological differences between the pollen obtained from clofencet-treated plants and untreated controls. The pollen grains from untreated controls were rounded, while the pollen grains from treated spikes were wrinkled and distorted (Figure 1).

\section{Discussion}

On the basis of the results obtained, clofencet induced male sterility in cultivars of Triticum aestivum and T. turgidum var. durum, butfemale fertility was not affected considerably by the clofencet doses used. However, it is pos- 


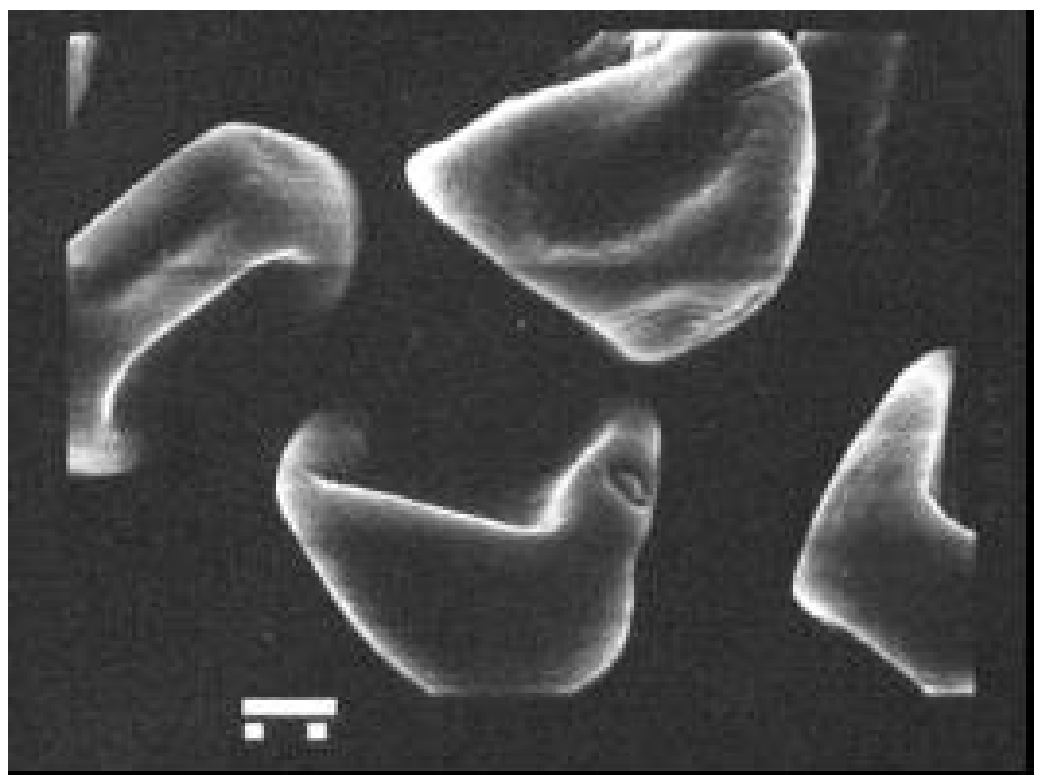

Figure 1. Sterile distorted pollen grains obtained in wheat spikes treated with the highest rate $\left(6.5 \mathrm{~kg} \cdot \mathrm{ha}^{-1}\right)$ of clofencet.

sible that higher clofencet doses may damage stigma, affecting grain formation (Nesvadba and Vyhnánek, 2001; Nesvadba et al., 2001). The highest clofencet doses induced low seed formation in this study, which may be attributed to the inability of pollen to fertilize the ovum. Previously, 41.3 and $56.3 \%$ cross pollination was obtained using 1.6, 3.6, and $4.9 \mathrm{~kg} \cdot \mathrm{ha}^{-1}$ of clofencet (Nesvadba and Vyhnánek, 2001) and Wassel and Weaver (1995) reported yields of 75 to $80 \%$ for hybrid seeds in comparison with untreated wheat.

The MS levels obtained, although high, were lower than expected, except for T. aestivum cv. Pía which had 96\% MS. According to Wong et al. (1995) 95\% MS is high enough for commercial hybrid seed production. Among other factors, the variable rate of MS obtained may be attributed to clofencet doses used, application dates, phenological state of the wheat plants, and to the differences in wheat species and cultivars.

The variability observed in seed number (Table 2) may be important in commercial wheat hybrid production. It is possible that the wheat cultivars used are slightly susceptible to CHA activity. They may require higher doses of clofencet than those applied in this study, or clofencet should be applied at different dates to achieve the desired MS. However, it has been reported that clofencet has good effectiveness in diverse genotypes and under different environmental conditions; but there is no reference to a possible species effect (Wassel and Weaver, 1995).

The doses and application dates had a considerable impact on the effectiveness of clofencet. The results obtained showed an increase of MS associated with high doses of clofencet. Independently of the wheat cultivar, $6.5 \mathrm{~kg} \cdot \mathrm{ha}^{-1}$ was the most effective dose, achieving 29.92 and 96.32\% MS with cultivars 'Capri' and 'Pía', respectively. Another study (Vyhnánek and Nesvadvba, 2000) has reported MS levels of $99.5 \%$ using $5 \mathrm{~kg} \cdot \mathrm{ha}^{-1}$; lower doses showed a minor efficiency, which was consistent with the results observed in this work. It is necessary to determine the possible negative effects on male fertility before the use high doses of clofencet $(>3.4$ to $6.7 \mathrm{~kg} \cdot \mathrm{ha}^{-1}$, EPA, 1997).

Regardless of the clofencet dose and wheat cultivar, the second application date, when wheat was at stage 8.5 of the Feekes scale, induced the highest MS, increasing 33.7 percentage points on average as compared with the clofencet applications performed early. Considering that 
only one clofencet application is commercially suggested, it is necessary to apply it at the precise time to induce maximum MS.

In wheat 'Capri' and 'Claudia', the preliminary analysis did not detect significant statistical differences between the lowest dose of clofencet used in the first application date and the untreated control. The average size of the spikes from these cultivars was smaller than the average size obtained in wheat 'Ambra' and 'Pía' when applying clofencet. In an earlier phenological state of wheat development, clofencet may have acted less efficiently.

In commercial plantings, variability in the phenological stages among plants is always obtained, particularly associated with the presence of tillers. The number and state of development of tillers may affect hybrid seed purity if seeds are not andro-sterilized within the wheat stages where plants are most susceptible to the CHA application. Therefore, a delayed application of clofencet may induce high MS in the main spike and in the neighboring tillers, as these tillers would be in a susceptible stage for CHA application. An adequate sowing density may diminish the number of tillers, improving the crop uniformity and decreasing the risk of forming self-pollinated seeds (Wong et al., 1995).

Nesvadba and Vyhnánek (2001) applied CHA at $500 \mathrm{~L} \cdot \mathrm{ha}^{-1}$ obtaining good results, and following the recommendation by Uauy et al., (2003) volumes lower than $1000 \mathrm{~L} \cdot \mathrm{ha}^{-1}$ should be used. Considering the systemic activity of clofencet, it would be advisable to use low volumes of water to avoid losses and ensure a higher precision in the effective doses. This could be achieved by the use of controlled drop applicators (CDA) using 15 to $20 \mathrm{~L} \cdot \mathrm{ha}^{-1}$, which would optimize the application.

Another factor affecting the expected results is the use of surfactants and humectants, as they favor penetration into the plant. The use of nonionic surfactants and humectants is suggested as carriers for clofencet (EPA, 1997). Wassell and Weaver (1995) indicate that the use of a surfactant may allow reducing the effective dose, which should be increased under low environmental humidity and when there is a greater variability in the morphological stages of the wheat plants. Nesvadba and Vyhnánek (2001) and Nesvadba et al. (2001) used the surfactant Mon8161 and the humectant Mon8165 in their experiments with clofencet (Genesis ${ }^{\circledR}$ ) obtaining $98 \%$ MS in $95 \%$ of the cases. Dash $\AA$, an adjuvant enabling the moistening and penetration of the compound spraying, was used in this experiment. Tests with several surfactants and humectants are required to determine which of them produce the best results along with clofencet.

The pollen observed with microscope showed morphological differences that may be the reason for the ME achieved. If the cytoplasmic pollen content is affected, it will not generate a normal pollen tube, hindering its germination and fertilization capacity. Clofencet is known to have systemic activity (Nesvadba and Vyhnánek, 2001; Nesvadba et al., 2001), but there is scarce information on its mode of action, although it is believed that the microspores abort before vacuolation (Uauy et al., 2003). This coincides with the results observed, as the pollen from the treated plants was collapsed and only showed the exine layer (Figure 1). Nesvadba et al. (2001) point out that the stamens of the treated plants were yellowish green and smaller, compared to the untreated plants. There was formation of pollen that was not released from the stamens and unable to be pollinated.

According to the results obtained, it is possible to conclude that clofencet showed some hybridizing activity, in particular in T. turgidum var. durum. Its suitability for commercial use depends on the induction of a high level of MS in the cultivar to be used as the female in the hyridization. Levels equal to or higher than 95\% MS are considered reasonable to ensure the quality of the hybrid seed. Its use in plant breeding programs is feasible as it enables the work of genetic improvers, allowing a higher amount of hybrid seed to be obtained than if the emasculations were made manually. As a tool for the production of hybrid seeds, it is noteworthy that only one application of the product is made, sprinkling the lines of female plants with cones to protect the male plants.

Because of the high MS (96.32\%) obtained in the cultivar 'Pía', clofencet is a viable choice 
as a male sterilizing agent for the production of hybrid wheat. However, its effectiveness is genotype-dependent. It is necessary to carry out tests of cross-pollination to determine the yield of hybrid seed. Further studies might in- duce a better performance if the aforementioned aspects are regarded, and they could determine the possible mode of action, the dose, state and optimal conditions of application, widening its use to a larger number of cultivars.

\section{Resumen}

\section{P.C. Parodi and M.A. Gaju. 2009. Macho esterilidad inducida por el agente hibridizante} químico clofencet en trigo, Triticum aestivum y T. turgidum var. durum. Cien. Inv. Agr. 36(2):267-276. Se realizó una evaluación del agente hibridizante químico clofencet (Genesis, Monsanto, EUA) en cuatro cultivares de trigo, dos harineros (Triticum aestivum) cvs. Pía y Claudia y dos trigos candeales (T. turgidum var. durum) cvs. Capri y Ambra. Se utilizó un diseño de bloques divididos con cinco repeticiones aplicando 03,$5 ; 5,0$ y $6,5 \mathrm{~kg} \cdot \mathrm{ha}^{-1}$ de clofencet, cuando las plantas alcanzaron los estadios 7,5 y 8,5 grados en la Escala de Feekes. Se midió la formación de grano para cada tratamiento como sistema de evaluación de macho esterilidad (ME). Los resultados indicaron que los niveles de ME alcanzados aumentaron con la dosis y con el estado más tardío de desarrollo (segunda fecha de aplicación) vegetativo del trigo. El promedio ME alcanzado con la dosis más alta fue de un 47,3\% en la primera fecha de aplicación y llegó a un $84 \%$ en la segunda fecha. Estos resultados, a pesar de mostrar un efecto importante del compuesto, no son suficientes para el propósito de obtener semilla híbrida, ya que el nivel de autopolinización fue alto. Unicamente el cultivar Pía alcanzó un 96\% de ME, facultando el uso del gametocida Genesis ${ }^{\circledR}$ para la producción de trigo híbrido. El insuficiente nivel alcanzado se pudo deber entre otros factores a las condiciones de aplicación (dosis, fecha, uso de humectantes, surfactantes, volumen de agua), la susceptibilidad de los cultivares, las condiciones ambientales y del cultivo (temperatura, humedad, estrés, tipo de suelo, homogeneidad).

Palabras clave: Triticum aestivum, Triticum turgidum, semilla híbrida, macho esterilidad, agente hibridante químico.

\section{References}

Bingham, J., and F.G.H Lupton. 1987. Production of new varieties: an integrated research approach to plant breeding. In: F.G.H. Lupton (ed.). Wheat Breeding: Its Scientific Basis. Chapman and Hall. London, England.

Braun, H.J., T.S. Payne, A.J. Morgounov, M. Van Ginkel, and S. Rajaran. 1998. The challenge: One billion tons of wheat by 2020. Proceeding $9^{\text {th }}$ International Wheat Genetics Symposium. Saskatoon, Saskatchewan, Canadá. 2-7 Agosto, 1998.

Bruns, R., and C.J. Peterson. 1998. Yield and stability factors associated with hybrid wheat. Pages 23-27. In: H.-J. Braun, F. Altay, W.E. Kronstad, S.P.S. Beniwal, and A. McNab, (eds.). Wheat: Prospects for Global Improvement, Ankara, Turquía, 10-14 Jun. 1996. Kluwer Academic
Publishers. Dordrecht, The Netherland.

Cisar, G., and D.B. Cooper. 2003. Hybrid wheat. In: Curtis, B.C., S. Rajaram, and H. Gómez Macpherson (eds.). Bread Wheat Improvement and Production. FAO Plant Production and Protection Series, No 30. FAO, Roma, Italia.

Cross, J., and P. Schulz. 1997. Chemical induction of male sterility. In: K.R. Shivana, and V.K. Sawhney (eds.). Pollen biotechnology for crop production and improvement. Cambridge University Press. Cambridge, England.

Curtis, B.C., S. Rajaram, and H. Gómez Macpherson (eds.). 2002. Bread Wheat Improvement and Production. FAO Plant Production and Protection Series, No 30. FAO, Roma, Italia.

Driscoll, C.J. 1985. Modified XYZ system of producing hybrid wheat. Crop Sci. 25:1115-1116.

Duvick, D.N. 1999. Commercial strategies for exploitation of heterosis. Pages 295-304. In: J. G.Coors, and S. Pandey (eds.). Genetics and Ex- 
ploitation of Heterosis in Crops. American Society of Agronomy, Inc., Crop Science Society of America, Inc., Soil Science Society of America, Inc., Madison, WI, USA.

Edwards, I. 1986. Breeding of hybrid varieties of wheat. Pages 2-24. In: I.B. Edwards, W.P. Feistritzer, and A.F. Kelly. (eds.). Hybrid Seed Production of Selected Cereal, Oil, and Vegetable Crops. FAO Plant Production and Protection Paper 82. FAO, Rome, Italy.

EPA. 1997. Pesticide fact sheet. Environmental Protection Agency. Washington, DC, USA.

Fichet, Y., and N. Adams. 1996. Clofencet: un nouvel agent d'hibridation chimique du blé. Pages 61-68. IN : Quatrieme Colloque. Les Substances de Croissance Partenaires Economiques des Productions Vegetales Paris, Francia.

He, Z.H., Z.H. Du, and Q.S. Zhuang. 1998. Progress of wheat breeding research in China. Pages 47-53. In: H.-J. Braun, F. Altay, W.E. Kronstad, S.P.S. Beniwal, and A. McNab (eds.). Wheat: Prospects for Global Improvement. Kluwer Academic Publishers. Dordrecht, The Netherland.

Hoagland, A.R., F. C.Elliott, and L.W. Rasmussen. 1953. Some histological and morphological effects of maleic hydrazide on spring wheat. Agron. J. 45:468-472.

Liable, C.A. 1974. Chemical methods for pollen control. Proc. 29th Ann. Corn and Sorghum Res. Conf. Pub. 29:174-182.

McRae, D.H. 1985. Advances in chemical hybridization. Plant Breeding Reviews 3:169-191.

Mock, J.J. 1995. A new look at hybrid wheat and its role in improving yield and quality. Pages 20 34. In: C.J. Peterson (ed.). Proc. North American Wheat Workers Workshop, Kansas City, MO, USA.

Murray, K. 1998. $\mathrm{F}_{1}$ seed production efficiency by using photoperiod-sensitive cytoplasmic male sterility and performance of $F_{1}$ hybrid lines in wheat. Breeding Science 48:35-40.

Nesvadba, Z., and T. Vyhnánek. 2001. Induction of hybrid wheat using the gametocide Genesis ${ }^{\circledR}$ in the Czech Republic. Acta Univ. Agric. et Silvic. Mendel. Brun. 49: 27-35.

Nesvadba, Z., T. Vyhnánek, and J. Vendar. 2001. The testing of efficacy of CHA Genesis ${ }^{\circledR}$ for production of hybrid wheat and hybrid triticale. Acta Fytotechnica et Zootechnica 4:266-268.

Nesvadba, Z., F. Machán, P. Laml, and J. Spunar. 1998. Derzeitiger stand und perspektiven der hybridzüchtung bei winterweizen und triticale in der Tschechischen Republik. Bericht über die 48. Züchtertagung, Gumpenstein 25-27:33-37.

Parodi, P., F.L. Patterson, and W.E. Nyquist. 1970. Interrelaciones entre los componentes principales y secundarios de rendimiento en trigo, Triticum estivum L. Fitotecnia Latinoamericana 7:1-15.

Pickett, A.A. 1993. Hybrid Wheat: Results and Problems. Paul Parey Scientific Publishers. Berlin and Hamburgo, Germany.

Pingali, P.L., and S. Rajaram. 2000. Global wheat research in a changing world: Options for sustaining growth in wheat productivity. Part 1. In: World Wheat Facts and Trends 1998/1999. CIMMYT, México, D.F. México.

Rajaram, S. 1999. Approaches for breaching yield stagnation in wheat. Genome 42:629-634.

Rathgeb, W., I.M. Nebreda, and P.C. Parodi. 1982a. Interacción de macho esterilidad con gametocidas químicos. I. Trigo (Triticum aestivum L Ciencia e Investigación Agraria 9:127-142.

Rathgeb, W., I.M. Nebreda, and P.C. Parodi. 1982b. Interacción de macho esterilidad con gametocidas químicos. II. Triticale (X Triticosecale Wittmack). Ciencia e Investigación Agraria 9:157-170.

Skovmand, B. S. Rajaram, J.M. Ribaut, and A.R. Hede. 2003. Wheat genetic resources. In: Curtis, B.C., S. Rajaram, and H. Gómez Macpherson (eds.). Bread Wheat Improvement and Production. FAO Plant Production and Protection Series, No 30. FAO, Rome, Italy.

Uauy, C., P.C. Parodi, and A. Vidal. 2003. Trigo híbrido: desde macho esterilidad citoplasmática hasta agentes hibridizantes químicos. In: M.M. Kholí, M. Díaz,and M. Castro (eds.). Estrategias y Metodologías Utilizadas en el Mejoramiento de Trigo. Seminario Internacional, La Estanzuela, Uruguay. CIMMYT-INIA.

Virmani, S.S., and I.B. Edwards. 1983. Current status and future prospects for breeding hybrid rice and wheat. Adv. Agron. 36:145-214.

Wassell, L., and V. Weaver. 1995. Benefits of hybrid wheat. HybriTech Product Development Report. Monsanto and HybriTech Seed International Inc. St. Louis, MO, USA.

Wilson, J.A. 1984. Hybrid wheat breeding and commercial seed development. Plant Breeding Reviews 2:303-319.

Wong, M., A. Blouet, and A. Guckert. 1995. Effectiveness of SC2053 as a chemical hybridizing agent for winter wheat, importance of developmental stages and doses of application. Plant Growth Regulation 16:243-248. 